Research Article

\title{
Mechanical and Durability Properties of Induction-Furnace-Slag-Incorporated Recycled Aggregate Concrete
}

\author{
Syed Ishtiaq Ahmad (iD) and Md. Shafiqur Rahman \\ Department of Civil Engineering, Bangladesh University of Engineering and Technology, Dhaka, Bangladesh \\ Correspondence should be addressed to Syed Ishtiaq Ahmad; siahmad@ce.buet.ac.bd
}

Received 9 August 2018; Revised 23 October 2018; Accepted 1 November 2018; Published 26 November 2018

Academic Editor: Libo Yan

Copyright (c) 2018 Syed Ishtiaq Ahmad and Md. Shafiqur Rahman. This is an open access article distributed under the Creative Commons Attribution License, which permits unrestricted use, distribution, and reproduction in any medium, provided the original work is properly cited.

\begin{abstract}
Most of the steel mills in Bangladesh use induction furnace which produces large quantities of slags that have very little use except land filling. Therefore, feasibility of using this slag is examined in concrete with recycled aggregate, which is another waste product that is generated due to removal of old structures. Concrete with three target strengths, $17.23,20.68$, and 24.13 MPa, was prepared using recycled concrete acquired from a recently demolished building in Dhaka, Bangladesh. Recycled coarse aggregate was replaced with induction furnace slag by $0 \%, 25 \%, 50 \%, 75 \%$, and $100 \%$ for each target strength. Samples prepared from these concretes were tested for workability, compressive strength, splitting tensile strength, modulus of elasticity, and durability properties e.g., porosity, absorption, and rapid chloride penetration. Review of test results suggests that workability of concrete was not adversely affected by incorporation of induction furnace slag. For up to $50 \%$ of induction furnace slag replacement, both compressive strength and splitting tensile strength increased in recycled aggregate concrete. Further, for all ratios of induction furnace slag replacement, modulus of elasticity increased compared to $100 \%$ recycled aggregate concrete. Porosity and absorption also decreased in concrete where up to $50 \%$ of recycled aggregate was replaced by induction furnace slag. Considering these, it is concluded that $50 \%$ of recycled aggregate can be replaced by induction furnace slag that will result in superior mechanical and durability properties in recycled aggregate concrete.
\end{abstract}

\section{Introduction}

Bangladesh has been experiencing a rapid boom in construction sector in recent years backed by high economic growth rate. As concrete is the primary material of construction, this is putting strain on limited resources, particularly aggregate, the main component of concrete. One way of alleviating high demand on aggregate may come through by using demolished concrete from old and or unserviceable buildings as recycled aggregate (RA). The global concrete and masonry rubble production due to demolition of old structure is estimated to be one billion tons annually [1]. In recent years, demolition of structures has become a commonplace event in Bangladesh as many old buildings have to make way for new high-rise structures. This process is generating a large quantity of demolished concrete which may be used as aggregate for new concrete production. This will also alleviate disposal problem of this waste product. A number of studies have been reported in the available literature regarding the use of demolished concrete as aggregate [2-13]. However, many of those studies have found degradation in mechanical and durability properties when natural aggregate (NA) was replaced by decreased compressive strength, indirect shear strength, and modulus of elasticity in recycled aggregate concrete (RAC) observed by Rahal [3]. Tabsh and Albdefatah [4] have reported that strength of RAC can be 10-25\% lower than that of conventional concrete made with NA. Increased deformations by creep of $51 \%$ and by shrinkage of $70 \%$ were also observed in RAC compared to natural aggregate concrete (NAC) [6, 7]. Butler et al. [8] showed that bond strength between concrete reinforcing bar is 9 to $19 \%$ lower 
in RAC compared to NAC. Xu et al. [9] found that replacement rates up to $3 \%, 30 \%$, and $50 \%$ for recycled power, recycled fine aggregate, and recycled coarse aggregate, respectively, could be applied in concrete mixture design without deteriorating concrete strength. Jin et al. [10] investigated concrete produced from recycled redbrick and demolished concrete and suggested "prewetting" method to improve the mechanical properties of recycled aggregate concrete. The poor performance of the RAC is associated with the cracks and fissures, which are formed in RA during processing, thereby rendering the aggregate susceptible to permeation, diffusion, and absorption of fluids [11]. Many researchers have also worked on improving the quality of RAC using different approaches. For example, Dimitriou et al. [12] suggested treatment method and admixtures to improve the quality of RAC. Whereas, Xuan et al. [13] examined improved durability performance of carbonated recycled concrete aggregate. In this work, investigation was carried out to check whether mechanical and durability properties of RAC can be enhanced by partially replacing it with induction furnace slag (IFS) which is a steel industry waste product.

Bangladesh has an annual consumption of about four million tons of steel that is met by around four hundred steel mills. Except one, almost all mills use relatively old system of induction furnace for melting steel scrap instead of modern electric arc furnace. As by-product of this melting process, a large amount of slag is produced which is termed as IFS. The American Society for Testing and Materials (ASTM) define steel slag as a nonmetallic product, consisting essentially of calcium silicates and ferrites combined with fused oxides of iron, aluminium, manganese, calcium, and magnesium that are developed simultaneously with steel in basic oxygen, electric arc, or open-hearth furnaces [14]. There is no official data on the amount of slag that is produced per annum in Bangladesh. Nonetheless, about 11 to $15 \mathrm{~kg}$ slags are generated from per ton production of steel in induction furnace [15]. Considering this, the annual slag production in Bangladesh is estimated to be about 60000 ton. Until now, except land filling, there is no alternative use of this large quantity of slag. But land filling option is gradually reduced as available land to fill is becoming scarce. Hence, disposal of this slag is a big concern for steel industries. Any viable use of this slag, for instance, as construction material, will not only alleviate disposal problem but will also benefit the construction sector. A number of studies have been reported in the literature regarding IFS-incorporated concrete. Qurishee et al. [16] studied strength of concrete using IFS as a replacement for coarse aggregates and compared it with NAC. They found that the compressive and tensile strength increased when up to $40 \%$ NAC was replaced by IFS. John and John [17] replaced fine aggregate by crushed IFS. They found that the compressive strength of mortar and concrete containing IFS up to 30 percent as fine aggregate is comparable with the strength of concrete with $100 \%$ sand. Andrews et al. [18] discussed the application of IFS and cupola furnace slag from different industries in Ghana as aggregate in concrete and as road bed material.

A few attempts have also been reported in the available literature regarding the use of IFS as replacement in concrete produced from alternative coarse aggregate. Mohammed et al. [19] examined mechanical properties of brick aggregate concrete with partial IFS and have found compressive strength and modulus of elasticity of concrete to be similar or better than $100 \%$ brick aggregate concrete. However, IFSincorporated RAC, which has not been examined elsewhere, may provide an alternative and useful way of utilising both RA and IFS. For this, concrete of three target strengths i.e., $\quad 17.23 \mathrm{MPa}$ (2500 psi), $20.68 \mathrm{MPa}$ (3000 psi), and $24.13 \mathrm{MPa}(3500 \mathrm{psi})$ was produced where RA was replaced by IFS by $0 \%, 25 \%, 75 \%$, and $100 \%$ for each of the target strength. Several mechanical and durability properties of fresh and hardened concrete were measured that included slump value, compressive strength, splitting tensile strength, modulus of elasticity, porosity, void ratio, and rapid chloride penetration value to examine the effect of IFS addition. Through review of these test results, recommendations were devised regarding appropriate mixing ratio that may act as guideline for effective use of these two waste products.

\section{Materials Used and Methods}

2.1. Cement. Ordinary Portland cement (type I of ASTM C150 [20]) was used for preparation of all concrete samples. Thus, cement properties remained constant and had uniform effects on strength and durability of concrete samples prepared by varying IFS and RA.

2.2. Fine Aggregate. A single type of natural coarse sand as fine aggregate was used throughout the experimental work so as to keep the fine aggregate parameter constant. Sieve analysis was carried out in accordance with ASTM C136 [21]. The results of this analysis showed that the sand used fitted within the limits set out in ASTM C33 [22]. Unit weight of fine aggregate was also determined in accordance with ASTM C29 [23], whereas water absorption and specific gravity of fine aggregate were found in accordance with ASTM C128 [24]. From these testing procedures, fineness modulus, unit weight, water absorption, and specific gravity of fine aggregate were found as $2.50,1584 \mathrm{~kg} / \mathrm{m}^{3}, 1.87 \%$, and 2.61 , respectively.

2.3. Recycled Aggregate. In this work, recycled aggregate was acquired from a recently demolished building in Dhaka, Bangladesh (Figure 1). Concrete chunks collected from this site were broken into pieces using a hammer. These broken pieces were segregated using standard sieve of size $25 \mathrm{~mm}$ or less. Those were then mixed together again (Figure 2) in a way so that particle size distribution of RA remained within the limits set out in ASTM C33 [22]. Size distribution and gradation of RA are shown in Figure 3 from which fineness modulus (FM) was found to be 7.52. Additionally, water absorption for saturated surface dry (SSD) condition, unit weight, specific gravity, and moisture content of recycled aggregate were measured and are reported in Table 1.

2.4. Induction Furnace Slag (IFS). IFS used in this work was collected from a large steel manufacturing industry located 


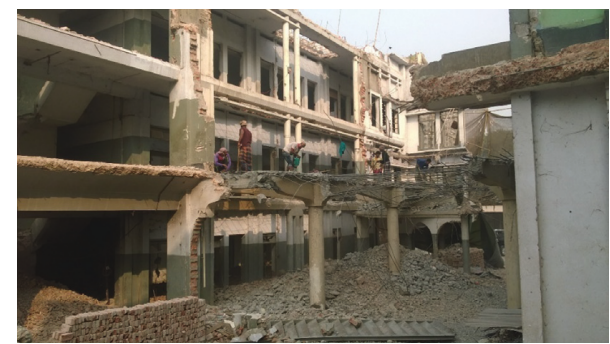

FIgURE 1: Demolition of existing building.

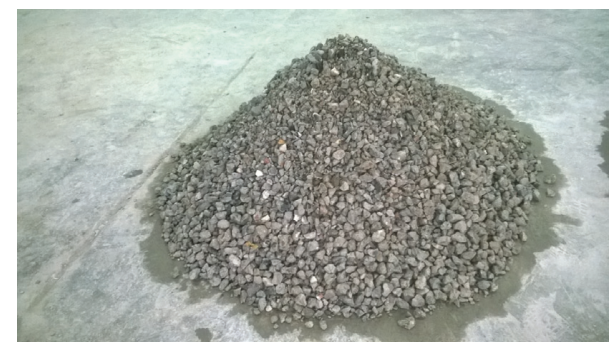

FIGURE 2: Stack of recycled aggregate to be used in fresh concrete.

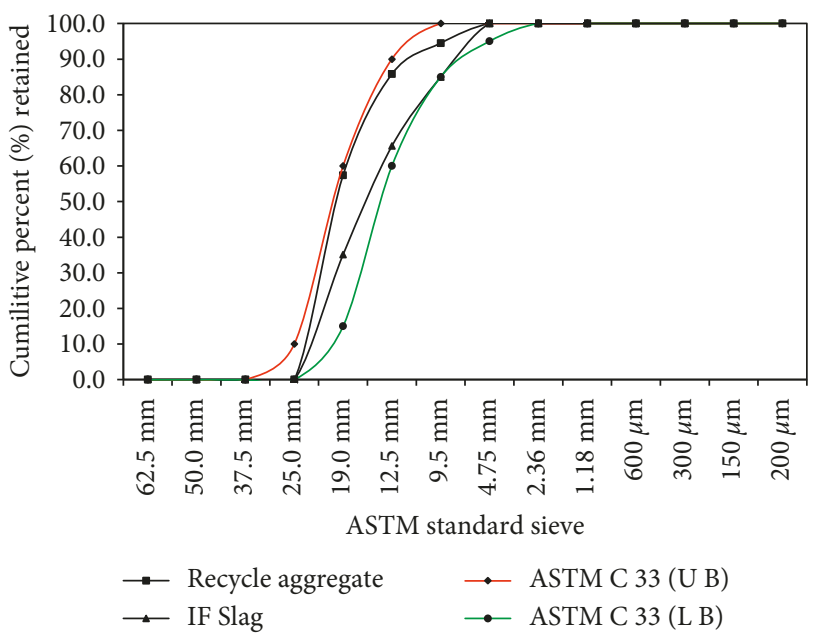

Figure 3: Gradation curve of recycled and IFS aggregate.

TABLE 1: Material properties of coarse aggregate.

\begin{tabular}{lccc}
\hline \multirow{2}{*}{ Properties } & \multirow{2}{*}{ Test standard } & \multicolumn{2}{c}{ Materials } \\
& & RA & IFS \\
\hline Bulk density $\left(\mathrm{kg} / \mathrm{m}^{3}\right)$ & ASTM C29 [23] & 1406 & 1462 \\
Specific gravity (SSD) & ASTM C127 [25] & 2.46 & 2.75 \\
Absorption capacity (\%) (SSD) & ASTM C127 [25] & 4.43 & 1.5 \\
Field moisture content (\%) & ASTM C566 [26] & 6.26 & 3.9 \\
\hline
\end{tabular}

at Chittagong, Bangladesh (Figure 4). Slag particles were first separated according to standard sieve size of $25 \mathrm{~mm}$ and smaller (Figure 5). IFS aggregate of different sizes was then mixed together in a way so that particle size distribution remained within the limits set out in ASTM C33 [22]. Figure 3 shows grading curve for IFS aggregate along with

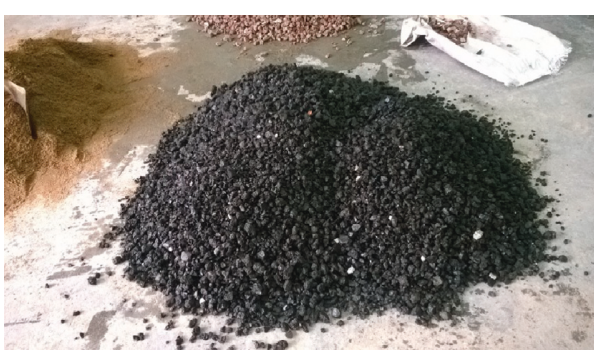

FIgURe 4: Stack of Induction Furnace slag.

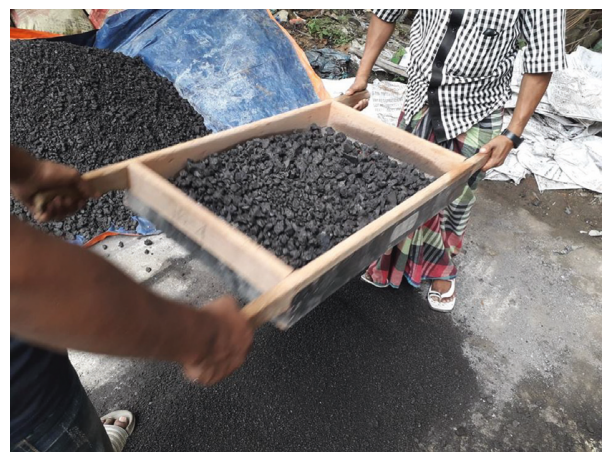

FIgURE 5: Sieving of IF slag using standard sieves.

the upper and lower limits specified in ASTM C33 [22]. From the gradation curve and size distribution, fineness modulus (FM) of IFS aggregate was found to be 7.19. Before casting of concrete with this slag aggregate, unit weight, specific gravity, absorption, and moisture content were measured as per relevant standards and are reported in Table 1. As can be seen from this table, both density and specific gravity of IFS are higher than RA; however, absorption capacity for SSD condition is much lower in IFS than RA.

The chemical composition of IFS slag was analysed by $\mathrm{X}$-ray fluorescence (XRF) analysis. XRF results (Table 2) show that major components of IFS used in the present study are $\mathrm{SiO}_{2}$ and $\mathrm{Fe}_{2} \mathrm{O}_{3}$. Apart from these, significant amounts of $\mathrm{Al}_{2} \mathrm{O}_{3}, \mathrm{MnO}$, and $\mathrm{CaO}$ are also present.

2.5. Mix Design and Mixing Method. In this research work, for mix designing of concrete, the ACI mix design method was used [27]. In that method, indicative w/c ratio diagram for concrete having different target strengths is provided. Using that diagram, w/c ratio for the target strength of 17.23, 20.68 , and $24.13 \mathrm{MPa}$ was $0.75,0.69$, and 0.63 , respectively, for slump between 25 and $50 \mathrm{~mm}$. Higher w/c ratios were maintained in this work compared to values like 0.4 to prevent workability problem which normally is mitigated by adding plasticizers in concrete. Addition of such plasticizer or admixture would have changed other properties of concrete. So, to find true variation of concrete properties for different IFS content, w/c ratio was high in this work, and no admixture was added to concrete.

For each target strength, samples were prepared by replacing RA with IFS by $0 \%, 25 \%, 50 \%, 75 \%$, and $100 \%$. 
TABLE 2: Chemical composition of IFS (\%).

\begin{tabular}{lcccc}
\hline $\mathrm{SiO}_{2}$ & $\mathrm{Fe}_{2} \mathrm{O}_{3}$ & $\mathrm{Al}_{2} \mathrm{O}_{3}$ & $\mathrm{MnO}$ & $\mathrm{CaO}$ \\
\hline 40.59 & 20.05 & 13.54 & 11.68 & 7.12 \\
\hline
\end{tabular}

For cases where both RA and IFS were present, weighted average value of unit weight and moisture content was considered in the process of mix design. Mix ratios evaluated from ACI 211 method [27] were converted to equivalent weight for $1 \mathrm{~m}^{3}$ of concrete and are shown in Table 3. Both $\mathrm{RA}$ and IFS were soaked in water for $48 \mathrm{~h}$ and added to the concrete mixture in a saturated surface dry (SSD) condition. Otherwise, a large part of water from mix design calculation would be soaked by the aggregate and would not be available to react with cement, changing the water-cement ratio. Water absorbed in the aggregate was in addition to the water requirement from mix design calculation as shown in $\mathrm{Ta}$ ble 3 . Fine aggregate was spread out by adding water for $48 \mathrm{~h}$ for making it SSD condition so that it did not absorb water which was added to concrete mix. The aggregates, cement, and water were then combined and mixed in a machine mixer as per ASTM C 192 [28]. The slump value was immediately checked for each concrete composition as per ASTM C143 [29]. For every set of concrete with a particular target strength, eighteen $200 \mathrm{~mm} \times 100 \mathrm{~mm}$ cylinders and three $100 \mathrm{~mm} \times 100 \mathrm{~mm} \times 100 \mathrm{~mm}$ cube samples were prepared. Cylinder specimens were subjected to compressive strength test as per ASTM C39 [30], tensile strength test as per ASTM C496 [31], and modulus of elastic test as per ASTM C469 [32]. Cube specimens were used to measure water absorption and porosity in hardened concrete as per ASTM C642 [33]. Samples prepared from cylinder specimens were subjected to rapid chloride penetration test (RCPT) as per ASTM C1202 [34].

2.6. Strength and Modulus of Elasticity of Concrete. Cylinder specimens with $100 \mathrm{~mm}$ diameter and $200 \mathrm{~mm}$ length were prepared for compressive and splitting tensile strength test. Cylinders were demolded after $24 \mathrm{~h}$ of casting and were kept in a submerged condition to meet the curing requirement as per ASTM C192 [28]. The specimens were brought out of water for compressive strength test at the age of 7, 28, and 90 days. Whereas, splitting tensile strength and modulus of elasticity were measured at the age of 28 days. The specimens were tested in a compression machine in the concrete laboratory with a loading rate of $3.0 \mathrm{kN} / \mathrm{sec}$ for compressive and tensile strength measurement. For modulus of elasticity measurement, much lower loading rate of $0.25 \mathrm{kN} / \mathrm{sec}$ was maintained as per code requirement [32]. Figure 6 shows failure surface of a RAC cylinder that contains IFS after compression test, whereas Figure 7 shows longitudinal strain being measured for a concrete cylinder under compressive load for determining modulus of elasticity.

2.7. Rapid Chloride Penetration Test. ASTM C1202 [34] was used to measure chloride penetration value of concrete.
For this, $100 \mathrm{~mm}$ diameter and $50 \mathrm{~mm}$ thick disc shape core samples were cut out from cylinder specimens after 28 days. Those samples were epoxy coated over the curved surface and vacuum saturated before being placed in testing chamber (Figure 8). The vacuum process was carried out to remove the air voids and to fill those voids with water to make the concrete sample conductive to electrons. A voltage of $60 \mathrm{~V} \mathrm{DC}$ was maintained across the ends of these samples for 6 hours (Figure 9). Readings were taken at every $30 \mathrm{~min}$ interval. At the end of the 6th hour, the sample was removed from the cell, and the amount of coulombs (C) passed through the specimen was calculated. Correlated value of chloride ion penetrability of concrete was evaluated from total charge measured in coulomb that passed through the sample.

\section{Results and Discussion}

3.1. Slump and Workability. Table 4 shows average slump value of concrete for three different target strengths with different IFS proportions. As can be seen, slump value remained with $25 \mathrm{~mm}$ to $50 \mathrm{~mm}$ as per mix design consideration. Hence, considering workability, the ACI mix design method [27] is applicable for IFS-incorporated concrete as well. Also, no segregation tendency was observed for IFS while mixing.

\subsection{Water Absorption and Porosity of Hardened Concrete.} Porosity and water absorptions are indication of pores or voids in concrete through which water or other liquids can permeate. Therefore, increase in these parameters results in corresponding increase in water permeability $[35,36]$. Consequently, porosity and water absorption are good indicators of durability characteristics of concrete. Porosity and water absorption of all RAC samples with or without different proportions of IFS are reported in Figures 10 and 11, respectively. As can be seen from these figures, both porosity and water absorption decreased as IFS replacement ratio was increased up to $50 \%$. For higher replacement ratio, both water absorption and porosity increased for all target strength. For 100\% IFS aggregate concrete, porosity and water absorption values were the highest for any particular target strength, even higher than $100 \%$ RAC. For 50\% IFS replacement, porosity and water absorption was found to be lowest among all replacement ratios. This signifies that equal proportions of IFS and RA make the internal structure of concrete more uniform throughout its volume with less pores. Therefore, considering porosity and water absorption, $50 \%$ is the optimum proportion of RA that may be replaced by IFS.

3.3. Compressive Strength of Concrete. Compressive strength $\left(f_{c}\right)$ of concrete with different IFS ratio for three different target strengths i.e., $17.23,20.68$, and $24.13 \mathrm{MPa}$ is shown in from Figures 12-14, respectively, for age up to 90 days. Review of these figures show that for 100\% RAC, 28-day target strength could only be achieved for $17.23 \mathrm{MPa}$ concrete. For 20.68 and $24.13 \mathrm{MPa}$ target strength, 28 days 
TABle 3: Concrete mix design (quantity for $1 \mathrm{~m}^{3}$ of concrete).

\begin{tabular}{|c|c|c|c|c|c|c|c|}
\hline \multirow{2}{*}{ Target strength $(\mathrm{MPa})$} & \multicolumn{2}{|c|}{ Coarse aggregate ratio } & \multirow{2}{*}{$\begin{array}{c}\text { Cement } \\
(\mathrm{kg})\end{array}$} & \multirow{2}{*}{$\begin{array}{c}\text { Sand } \\
(\mathrm{kg})\end{array}$} & \multirow{2}{*}{$\begin{array}{l}\mathrm{RA} \\
(\mathrm{kg})\end{array}$} & \multirow{2}{*}{$\begin{array}{l}\text { IFS } \\
(\mathrm{kg})\end{array}$} & \multirow{2}{*}{$\begin{array}{c}\text { Water } \\
(\mathrm{kg})\end{array}$} \\
\hline & RA (\%) & IFS (\%) & & & & & \\
\hline \multirow{5}{*}{17.23} & 100 & 0 & 237.35 & 893.87 & 955.73 & 0 & 178.22 \\
\hline & 75 & 25 & 237.35 & 968.43 & 682.78 & 227.59 & 178.22 \\
\hline & 50 & 50 & 237.35 & 984.18 & 456.37 & 456.37 & 178.22 \\
\hline & 25 & 75 & 237.35 & 993.52 & 227.62 & 682.85 & 178.22 \\
\hline & 0 & 100 & 237.35 & 990.53 & 0 & 966.16 & 178.22 \\
\hline \multirow{5}{*}{20.68} & 100 & 0 & 259.51 & 875.57 & 955.73 & 0 & 178.22 \\
\hline & 75 & 25 & 259.51 & 950.13 & 682.78 & 227.59 & 178.22 \\
\hline & 50 & 50 & 259.51 & 965.88 & 456.37 & 456.37 & 178.22 \\
\hline & 25 & 75 & 259.51 & 975.23 & 227.62 & 682.85 & 178.22 \\
\hline & 0 & 100 & 259.51 & 972.23 & 0 & 966.16 & 178.22 \\
\hline \multirow{5}{*}{24.13} & 100 & 0 & 283.75 & 855.57 & 955.73 & 0 & 178.22 \\
\hline & 75 & 25 & 283.75 & 930.13 & 682.78 & 227.59 & 178.22 \\
\hline & 50 & 50 & 283.75 & 945.88 & 456.37 & 456.37 & 178.22 \\
\hline & 25 & 75 & 283.75 & 955.22 & 227.62 & 682.85 & 178.22 \\
\hline & 0 & 100 & 283.75 & 952.23 & 0 & 966.16 & 178.22 \\
\hline
\end{tabular}

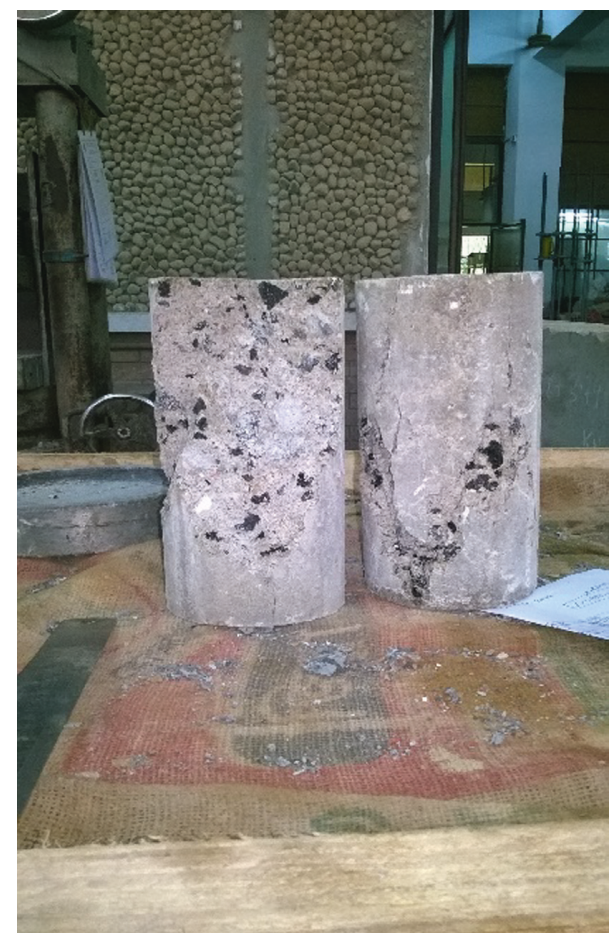

FIGURE 6: Failure surface of a recycled aggregate cylinder that contains IFS.

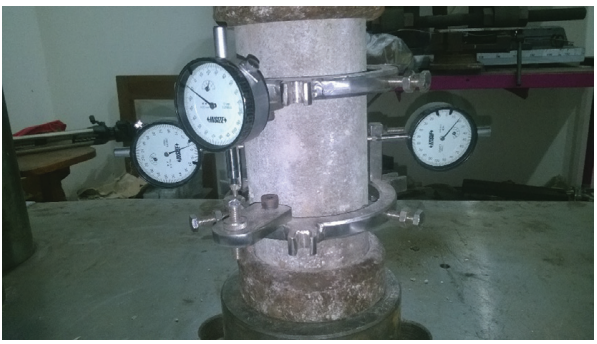

Figure 7: Test setup to determine modulus of elasticity.

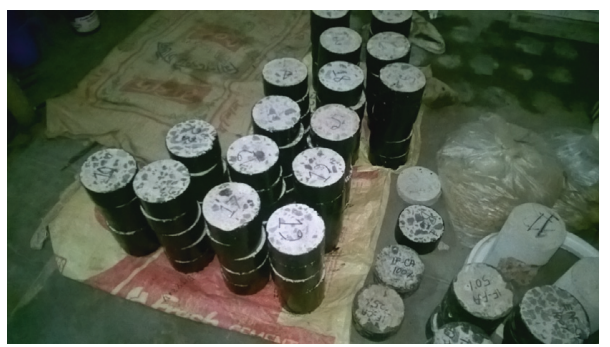

Figure 8: Specimens prepared for RCPT test.

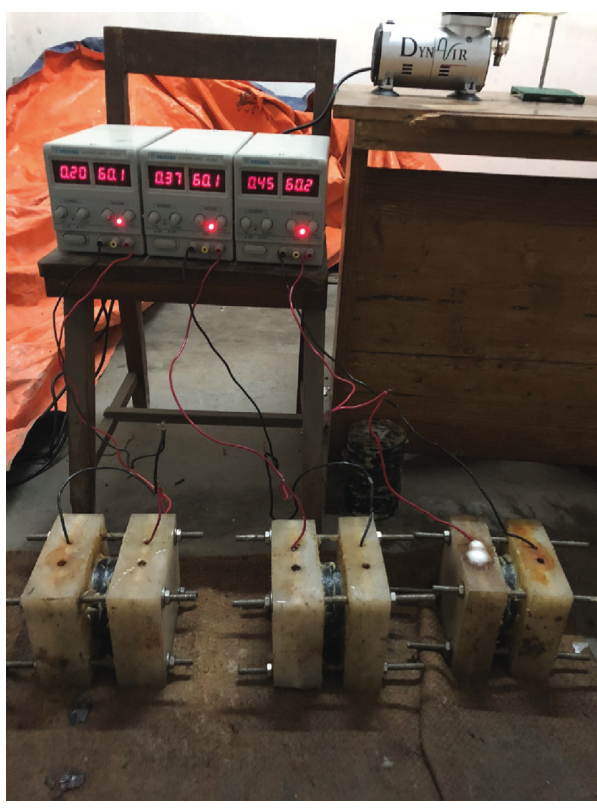

Figure 9: RCPT test being conducted.

strength was found to be $5.3 \%$ and $12.6 \%$ lower, respectively, than target strength. This is due to the fact that RA usually contains microcracks and hence more porous and softer 
TABLE 4: Slump value for concrete with different IFS ratio.

\begin{tabular}{lccc}
\hline Sl. no. & IFS (\%) & Strength (MPa) & Practical slump value in $\mathrm{mm}$ \\
\hline 1 & 0 & 17.23 & 45 \\
2 & 0 & 20.68 & 46 \\
3 & 0 & 24.13 & 48 \\
4 & 25 & 17.23 & 39 \\
5 & 25 & 20.68 & 30 \\
6 & 25 & 24.13 & 41 \\
7 & 50 & 17.23 & 32 \\
8 & 50 & 20.68 & 32 \\
9 & 50 & 24.13 & 34 \\
10 & 75 & 17.23 & 35 \\
11 & 75 & 24.13 & 31 \\
12 & 75 & 3500 & 30 \\
13 & 100 & 17.23 & 30 \\
14 & 100 & 20.68 & 32 \\
15 & 100 & 24.13 & 34 \\
\hline
\end{tabular}

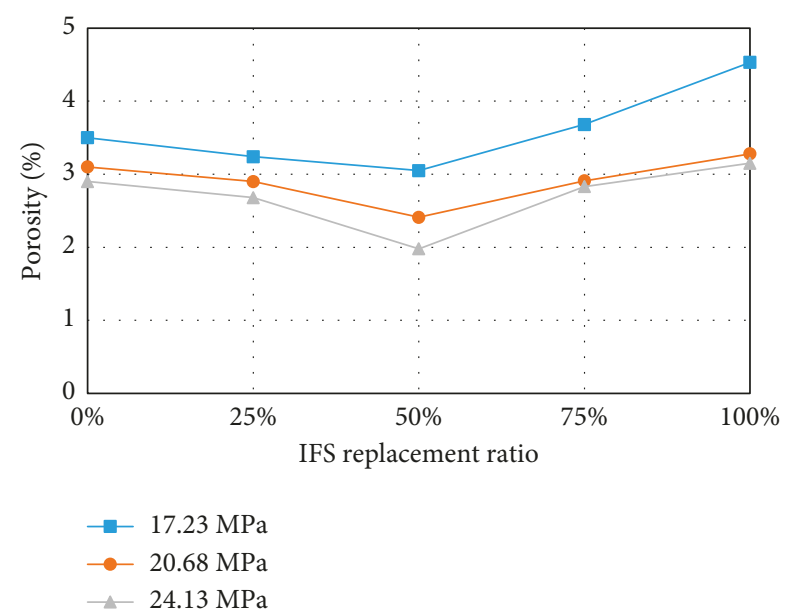

FIgURE 10: Porosity with respect to different IFS replacement ratio.

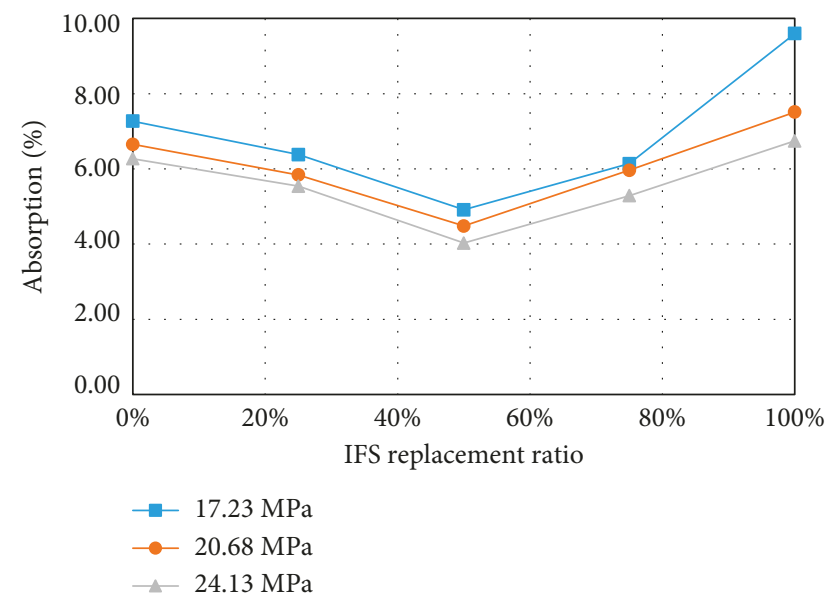

FIGURE 11: Absorption with respect to different IFS replacement ratio.

than virgin natural aggregate [11]. For this, many previous researchers failed to achieve respective target strength of concrete using RA [11, 37-39]. Compressive strength was

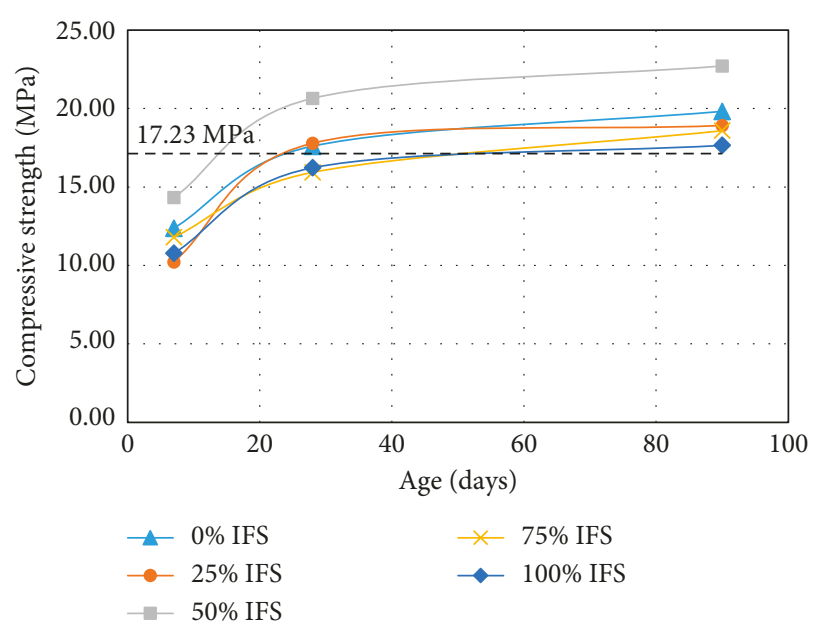

FIgure 12: Compressive strength with days for different IFS ratio (target strength: 17.23 MPa).

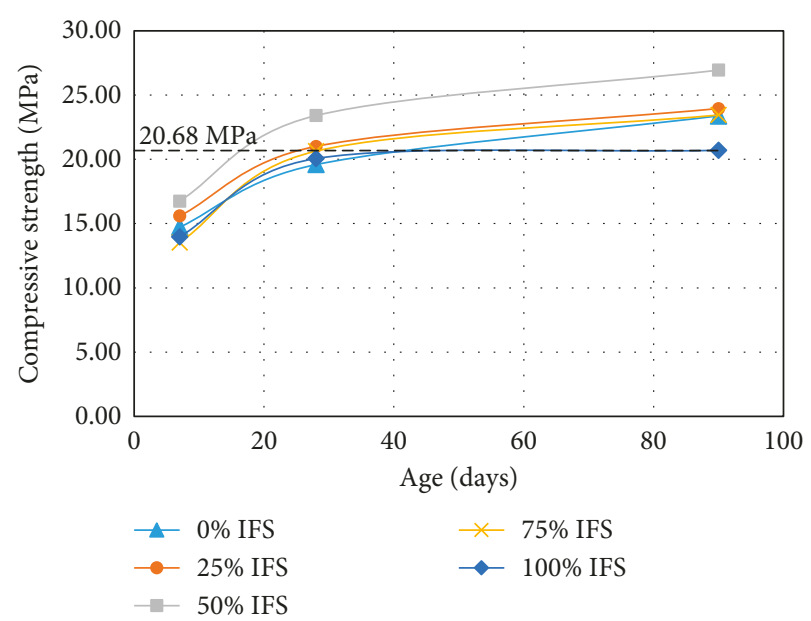

FIGURE 13: Compressive strength with days for different IFS ratio (target strength: $20.68 \mathrm{MPa}$ ).

found to increase even after 28th day. At 90th day $f_{c}$ of all samples with $100 \%$ RA exceeded respective design target strength.

As RA was increasingly replaced by IFS from $25 \%$ to $100 \%$, compressive strength behavior was found to vary. For up to $50 \%$ IFS replacement, $f_{\mathrm{c}}$ was found to increase with increasing replacement ratio. For $25 \%$ and 50\% IFS replacement, all three target strengths (17.23, 20.68, and $24.13 \mathrm{MPa})$ could be achieved at $28^{\text {th }}$ day. Highest $f_{\mathrm{c}}$, however, could be achieved for 50\% IFS-replaced concrete. For this replacement ratio, $f_{c}$ was higher than that of respective $0 \%$ and $25 \%$ IFS-replaced concrete by $14.2 \%$ to $28.6 \%$ at $28^{\text {th }}$ day for the three target strength examined. This difference is greater in concrete with higher target strength. Compressive strength with $50 \%$ IFS-replaced concrete was also found to be highest at $90^{\text {th }}$ day.

As IFS replacement was increased from $50 \%$ to $75 \%$ and $100 \%$, compressive strength was found to decrease with increasing replacement ratio. For these two replacement ratios (i.e., 75\% and 100\%), design compressive strength 


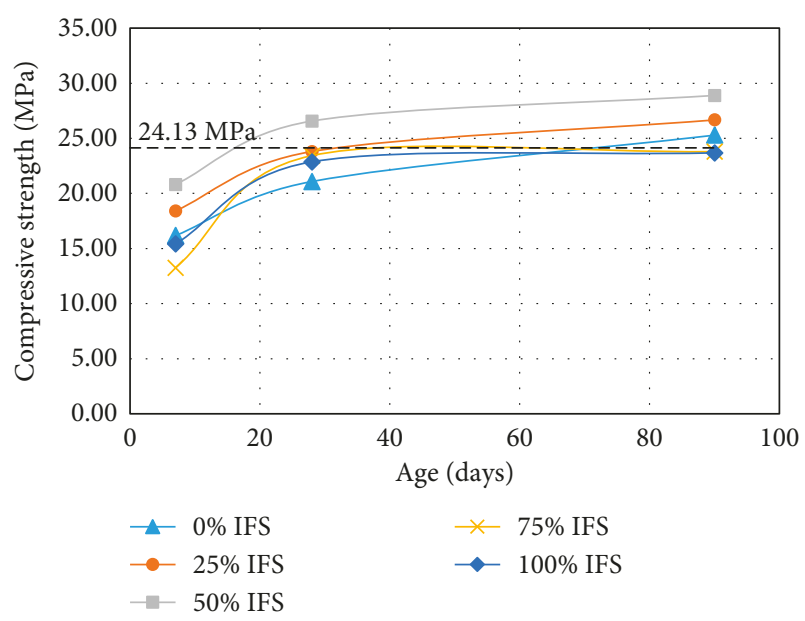

FIgURe 14: Compressive strength with days for different IFS ratio (target strength: $24.13 \mathrm{MPa}$ ).

could not be achieved at $28^{\text {th }}$ day. At $90^{\text {th }}$ day, $f_{c}$ increased but was lower than the target strength of 24.13 MPa. From these discussions, it is evident that, up to $50 \%$ of RA may be replaced by IFS considering compressive strength behavior. Higher than $50 \%$ of IFS would eventually reduce the compressive strength of RAC. In a similar way, Qurishee et al. [16] observed that up to $40 \%$ natural aggregate may be replaced by IFS without affecting its compressive strength. Likewise, Muhammed et al. [19] suggested 40\% steel slag replacement for brick aggregate concrete. One of the main reasons behind highest compressive strength of RAC containing 50\% IFS is that, for this mix ratio, porosity was found to be the lowest (Figure 10) among all target strengths. Equal proportions of IFS and RA formed a compact mix in concrete matrix which is evident from lowest pore spaces. It has been reported previously that opposite relationship exists between concrete porosity and compressive strength of concrete [40]. Hence, concrete compressive strength was found to be highest for 50\% IFS replacement.

Next, compressive strength of concrete for three different target strengths and with different IFS ratio was proportioned to compressive strength of corresponding $100 \%$ RAC. This was then plotted against IFS replacement ratio (Figure 15). From this figure, trend of change of compressive strength with change in IFS replacement ratio can easily be comprehended. It is again evident from the plotted trend line that for 50\% IFS replacement ratio, compressive strength increase was highest compared to $100 \%$ RAC. Two trend equations are also proposed, one each for below and above 50\% IFS replacement ratio, and are shown in Figure 15. In these equations, " $x$ " denotes IFS replacement ratio and " $y$ " denotes the factor by which compressive strength would increase compared to $100 \%$ RAC for that amount of IFS replacement. Using these equations, compressive strength of RAC for any amount of IFS replacement ratio can be predicted.

3.4. Splitting Tensile Strength of Concrete. Figure 16 shows splitting tensile strength $\left(f_{\mathrm{t}}\right)$ of concrete at 28th day for

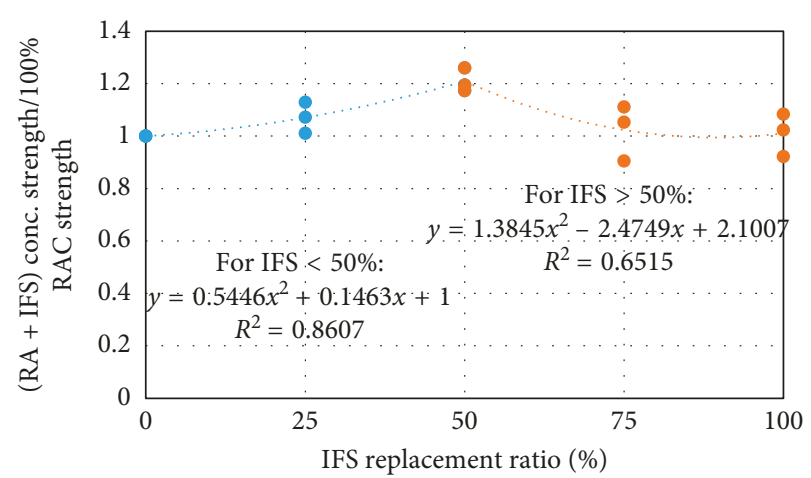

FIGURE 15: Compressive strength ratio between RA + IFS and 100\% RAC with respect to IFS replacement ratio.

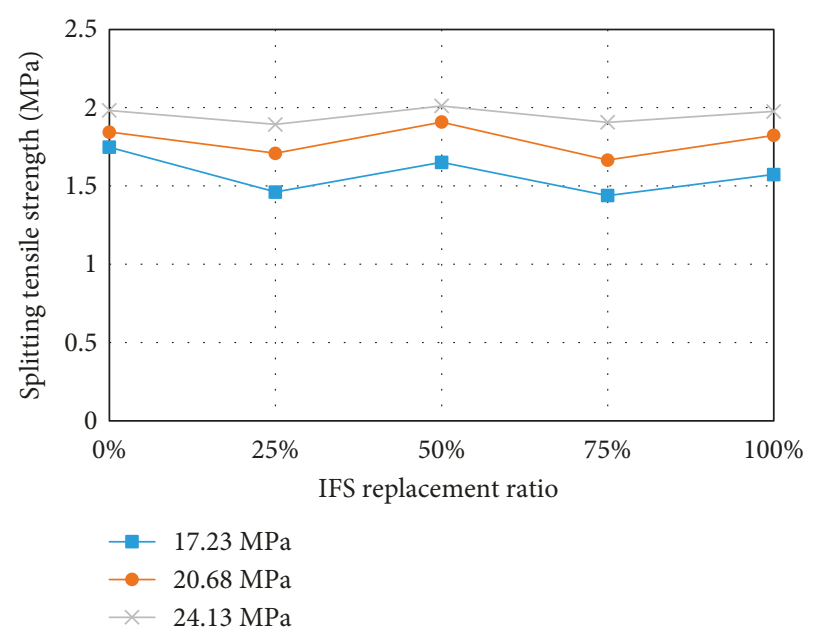

FIGURE 16: Splitting tensile strength for concrete with different IFS ratio.

different target strengths with different IFS ratios. With increase in target compressive strength, $f_{\mathrm{t}}$ was also found to increase. Again, as RA was replaced by IFS, $f_{\mathrm{t}}$ was found to vary from 100\% RAC. For 25\% IFS replacement, splitting tensile strength was found to be lower than concrete with $100 \%$ RA for all three target strengths. For 50\% IFS replacement, splitting tensile strength was higher than concrete with both $0 \%$ and $25 \%$ IFS. For 75\% RA replacement, splitting tensile strength decreased. Splitting tensile strength of $100 \%$ IFS concrete was, however, higher than $75 \%$ IFSreplaced concrete but lower than $100 \%$ RAC. Like $f_{c}, f_{\mathrm{t}}$ was found to be highest for RAC with 50\% IFS replacement for all three target strengths.

Increase or decrease in tensile strength of RAC for different IFS replacement ratio was essentially due to increase or decrease in compressive strength of corresponding concrete as proportional relationship exists between compressive and tensile strength of concrete. The rate at which tensile strength varied with respect to compressive strength for different IFS replacement ratio is examined next. Figure 17 shows relationship between compressive strength $\left(f_{\mathrm{c}}\right)$ and tensile-compressive strength ratio $\left(f_{\mathrm{t}} / f_{\mathrm{c}}\right)$ at $28^{\text {th }}$ day for different IFS proportion. As evident from this figure, 


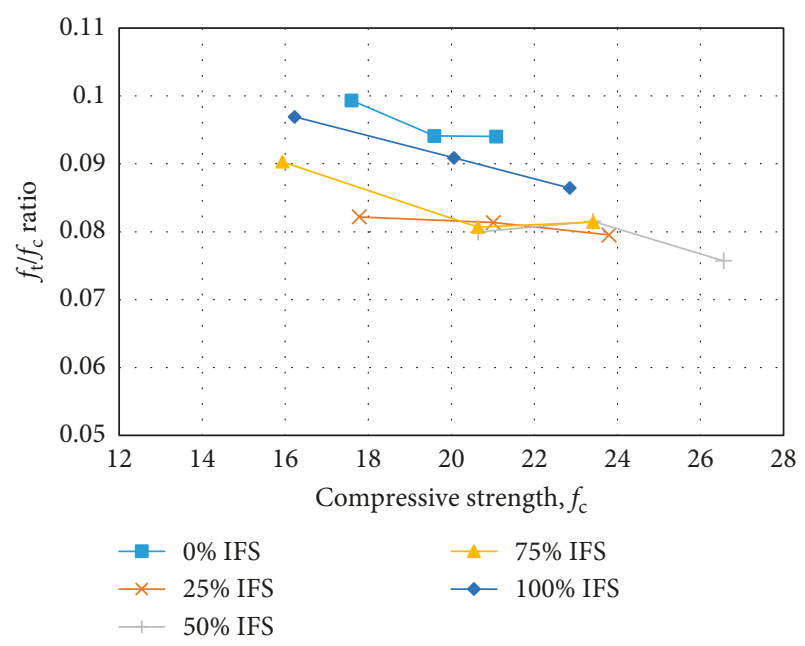

FIGURE 17: $f_{\mathrm{t}} / f_{\mathrm{c}}$ ratio with respect to compressive strength, $f_{\mathrm{c}}$.

$f_{\mathrm{t}} / f_{\mathrm{c}}$ ratio decreased with the increase in $f_{\mathrm{c}}$ for all concrete samples. Clearly, $f_{\mathrm{t}} / f_{\mathrm{c}}$ ratio was highest for $100 \%$ RAC, and its value ranged from 0.094 to 0.099 , i.e., tensile strength, $f_{\mathrm{t}}$ was 9.4 to $9.9 \%$ of $f_{\mathrm{c}}$ in $100 \%$ RAC. For $100 \%$ IFS concrete, $f_{\mathrm{t}} / f_{\mathrm{c}}$ ratio was found to be close to $100 \%$ RAC (0.086 to $0.096)$. However, as RA was partially replaced by IFS, $f_{\mathrm{t}} / f_{\mathrm{c}}$ ratio was found to decrease. For 25\%, 50\%, and $75 \%$ IFS replacement, $f_{\mathrm{t}} / f_{\mathrm{c}}$ value ranged from 0.075 to 0.082 . Lowest $f_{\mathrm{t}} / f_{\mathrm{c}}$ ratio of 0.075 was observed for $24.13 \mathrm{MPa}$ concrete where $50 \%$ RA was replaced by IFS. From this, it is concluded that increase in tensile strength with respect to increase in compressive strength is lower in IFS-replaced RAC compared to $100 \%$ RAC.

3.5. Modulus of Elasticity of Concrete. Modulus of elasticity (MoE) of RAC with different IFS proportions was calculated using following equation as per ASTM C469 [32] from respective stress-strain relationship:

$$
E_{\mathrm{C}}=\frac{\sigma_{2}-\sigma_{1}}{\varepsilon_{2}-0.00005}
$$

where, $\sigma_{2}$ is the stress corresponding to the $40 \%$ of the peak load, $\sigma_{1}$ is the stress corresponding to strain of 0.00005 , and $\varepsilon_{2}$ is the strain at the stress level $\sigma_{2}$.

Figures 18-22 show stress-strain relationship of $0 \%$, $25 \%, 50 \%, 75 \%$, and $100 \%$ IFS-replaced RAC, respectively, for three different target strengths. As may be seen from these figures, IFS-incorporated RAC essentially has similar shape, nature, and peak strain behavior as in 100\% RAC. However, for most of the cases, slightly steeper slope could be observed at initial part of stress-strain relationship of concrete containing IFS than that in 100\% RAC. This is reflected in the MoE values shown in Figure 23. As evident from this figure, $\mathrm{MoE}$ was higher in every case of RAC containing IFS compared to $100 \%$ RAC. MoE was found to be highest for $100 \%$ IFS concrete for all three strengths. Increase in MoE with increasing IFS replacement ratio is due to the fact that aggregate type has major influence on MoE of concrete [41]. It has been observed by previous researchers

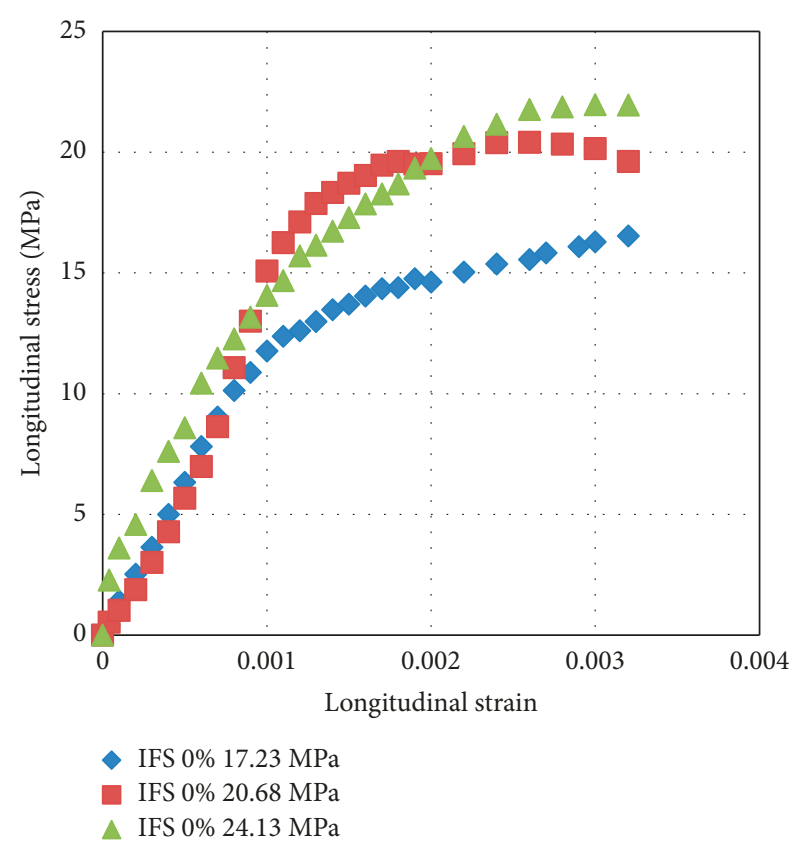

FIgURE 18: Longitudinal stress-strain diagram of 100\% RAC.

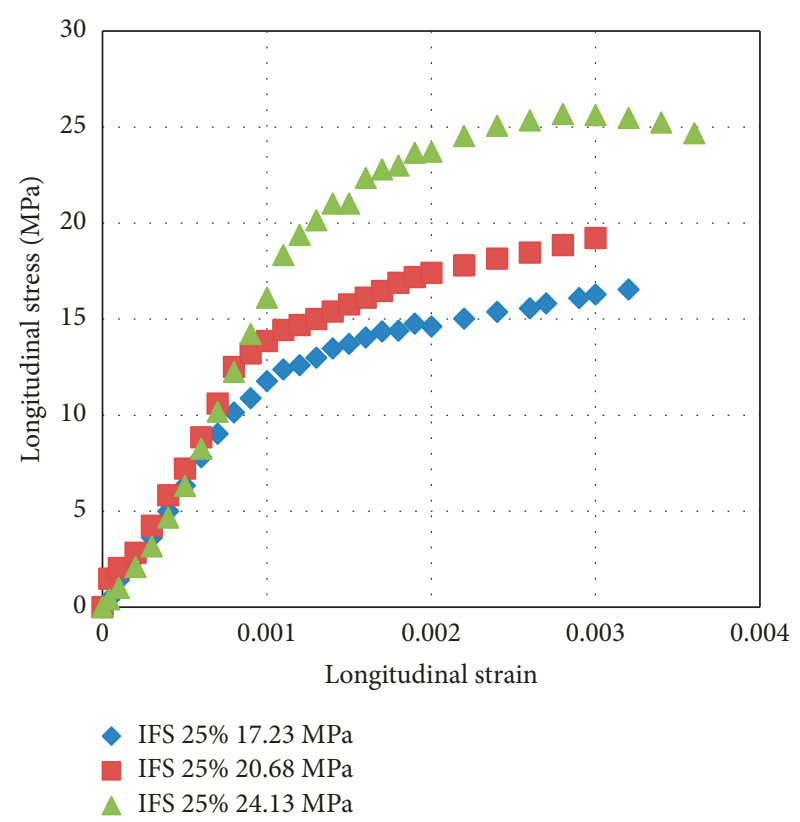

FIGURE 19: Longitudinal stress-strain diagram RAC with 25\% IFS.

that $\mathrm{MoE}$ of concrete containing softer aggregate was much lower $[42,43]$. Recycled aggregate used in this work was much softer than IFS as evident from their respective bulk density and specific gravity [Table 1]. As RA was replaced by IFS, average bulk density and specific gravity of combined aggregate enhanced, and, with this, $\mathrm{MoE}$ of concrete also increased. This was the main reason for increasing MoE of RAC with increasing IFS replacement. Similar increasing tendency of MoE was also observed by Mohammad et al. [19] in concrete where brick aggregate was replaced by steel slag. Therefore, it is concluded that incorporation of IFS increases MoE of recycled aggregate concrete. 


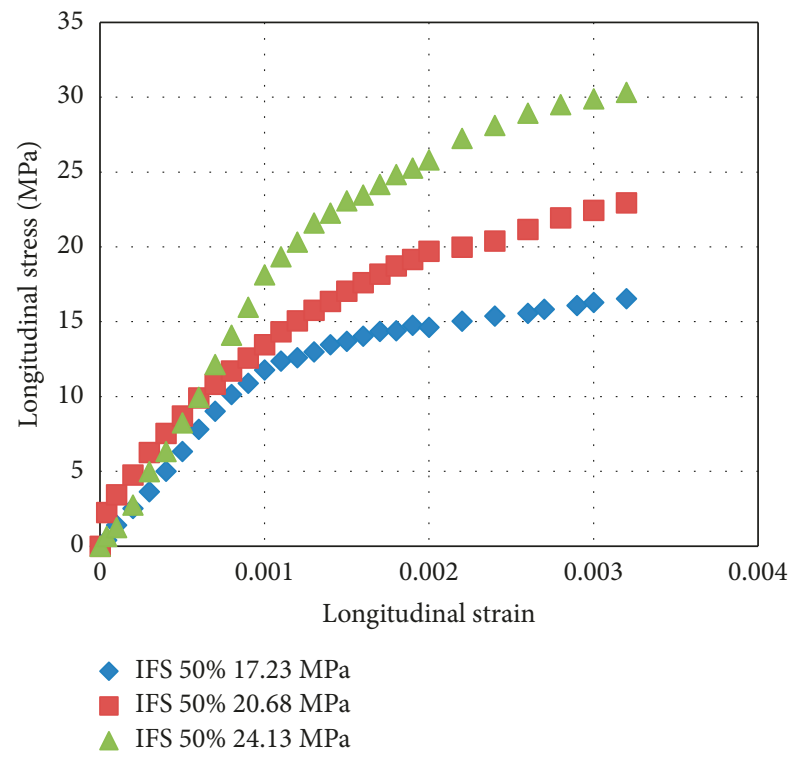

Figure 20: Longitudinal stress-strain diagram RAC with 50\% IFS.

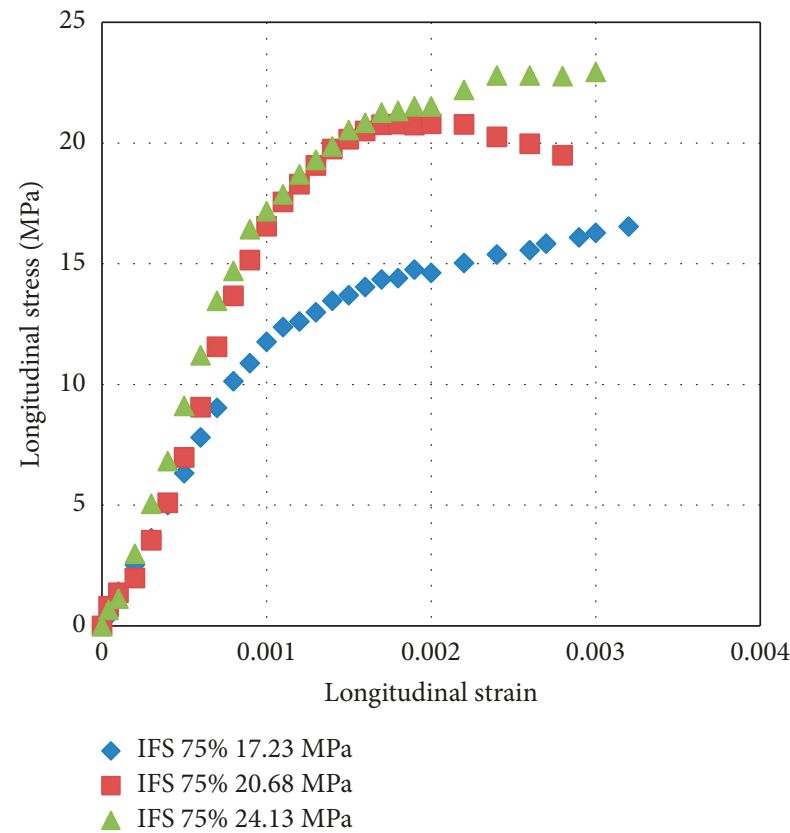

FIGURE 21: Longitudinal stress-strain diagram RAC with 75\% IFS.

3.6. Rapid Chloride Penetration Value. The RCPT test results for concrete with different target strengths and for different IFS ratios are shown in Figure 24. As per ASTM C1202 (34), if coulomb reading for any concrete sample is more than 4000 , it is characterized as "high chloride permeable". Concrete for which coulomb reading is between 2000 and 4000 , is termed as "moderate chloride permeable." As can be seen from Figure 24, both concrete with target strength of 17.23 MPa and 20.68 MPa have more than 4000 coulomb reading and hence may be categorized as high chloride permeable concrete. It is also apparent from Figure 24 that up to $50 \%$ addition of IFS as replacement for RA improves

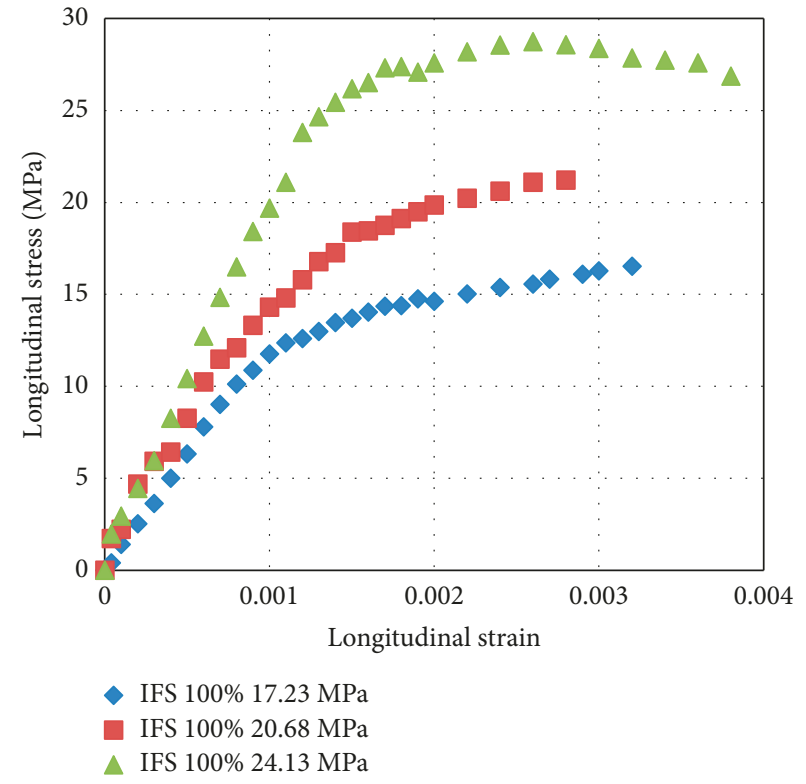

FIGURE 22: Longitudinal stress-strain diagram 100\% IFS concrete.

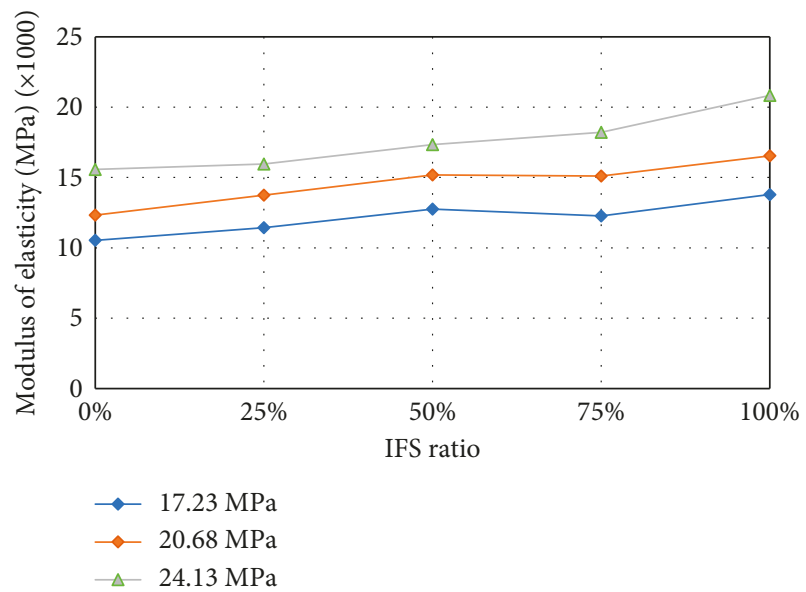

FIGURE 23: Modulus of elasticity of concrete for different IFS ratios.

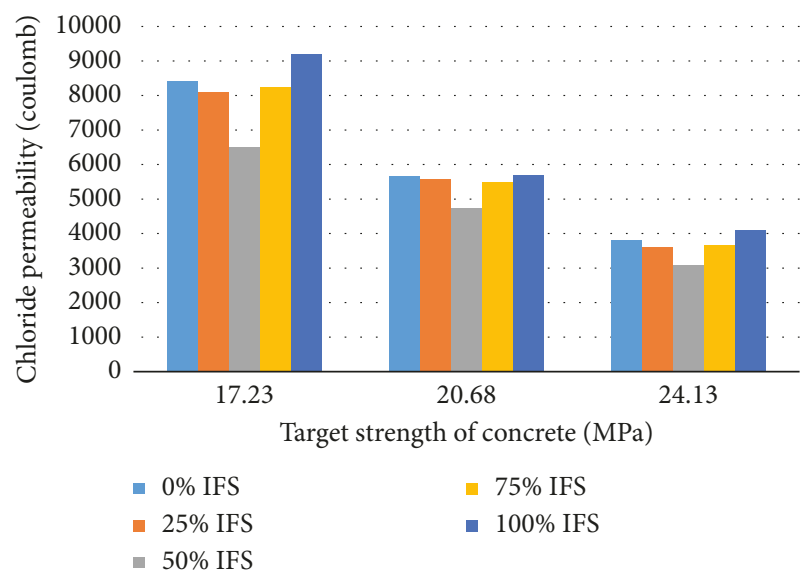

FIGURE 24: Chloride permeability of concrete for different target strengths and IFS ratios. 
the overall chloride permeability characteristics of RAC. For concrete with $50 \%$ IFS, chloride penetration value was found to be the lowest for any target strength. This is consistent with other parameters as concrete with $50 \%$ IFS resulted in highest compressive strength as well as lowest porosity and water absorption. Coulomb reading was found to increase with increase in IFS replacement ratio beyond 50\%. For all target strengths, $100 \%$ IFS concrete was found to give highest coulomb reading.

\section{Conclusion}

In this work, an extensive experimental program was conducted to examine the effect of incorporating IFS in RAC through partial and full replacement. Mechanical and durability properties of fresh and hardened concrete are examined through these testing programs. Following conclusions can be drawn based on experimental outcome from this work:

(i) Slump value of IFS-incorporated RAC remained within the target value as per the ACI mix design method [27]. No segregation tendency for IFS was observed during concrete mixing.

(ii) Porosity and water absorption were found to decrease for up to 50\% RA replaced by IFS. For higher replacement ratio, both porosity and water absorption increased. This signifies that equal proportions of IFS and RA make the internal structure of concrete more uniform throughout its volume with less pores. For any target strength, highest porosity and water absorption were observed for $100 \%$ IFS concrete.

(iii) For up to 50\% replacement of RA with IFS, compressive strength in RAC was found to increase. For more than $50 \%$ IFS replacement, compressive strength decreased. Equal proportions of IFS and RA formed a compact mix in concrete matrix that was uniform in nature throughout the concrete volume which is evident from lowest pore spaces. This was the main reason for the increase in compressive strength for $50 \%$ IFS replacement in RAC. Two equations to predict compressive strength of RAC for any IFS replacement ratio is also proposed.

(iv) Among all concrete cases examined in this work, splitting tensile strength was found to be highest for concrete with 50\% IFS. For partial IFS replacement $(25 \%, 50 \%$, and $75 \%)$, tensile strength ratio with respect to its compressive strength was found to be lower than 100\% RAC and 100\% IFS concrete.

(v) MoE of concrete increased for all ratios of IFS replacement compared to $100 \%$ RAC. For any target strength, highest MoE was observed for $100 \%$ IFS concrete. As RA was replaced by IFS, average bulk density and specific gravity of combined aggregate enhanced, which was one of the reasons for the increase in MoE of RAC when RA is replaced by IFS. (vi) RCPT test results also suggest that for any target strength, chloride penetration value of RAC may be reduced by replacing $50 \%$ RA with IFS. Chloride penetration value was higher in concrete where more than $50 \%$ RA was replaced by IFS.

Considering all these, it is concluded that up to $50 \%$ of RA may be replaced by IFS that will improve the strength, elasticity, and durability properties of concrete. The mechanical properties except $\mathrm{MoE}$ and durability properties were found to decrease in concrete where IFS replacement ratio was more than $50 \%$. Based on the current research findings, future research endeavors will focus on investigating the flexural, shear, and deformation behavior of reinforced concrete members like beams and columns made from IFSincorporated RAC. Long-term deformation characteristics of such reinforced concrete member will also be investigated.

\section{Data Availability}

The data used to support the findings of this study are available from the corresponding author upon request.

\section{Conflicts of Interest}

The authors declare that they have no conflicts of interest in publishing this paper.

\section{Acknowledgments}

The authors greatly acknowledge Bangladesh Steel Rerolling Mills (BSRM) Ltd. for providing induction furnace slag and bearing all logistic costs for that. The authors are grateful to the members and staff of the Strength of Materials and Concrete Laboratory of Department of Civil Engineering, Bangladesh University of Engineering and Technology (BUET), for their support and cooperation in conducting the tests. The authors are also grateful to the staff of Department of Glass and Ceramic Engineering, BUET, for conducting $\mathrm{XRF}$ analysis of induction furnace slag.

\section{References}

[1] P. K. Mehta, "Reducing the environmental impact of concrete," Concrete International-American Concrete Institute, pp. 61-66, October 2001.

[2] I. B. Topçu and S. Sengel, "Properties of concretes produced with waste concrete aggregate," Cement and Concrete Research, vol. 34, no. 8, pp. 1307-1312, 2004.

[3] K. Rahal, "Mechanical properties of concrete with recycled coarse aggregate," Building and Environment, vol. 42, no. 1, pp. 407-415, 2007.

[4] S. W. Tabsh and A. S. Abdelfatah, "Influence of recycled concrete aggregates on strength properties of concrete," Construction and Building Materials, vol. 23, no. 2, pp. 1163-1167, 2009.

[5] W. H. Kwan, M. Ramli, K. J. Kam, and M. Z. Sulieman, "Influence of the amount of recycled coarse aggregate in concrete design and durability properties," Construction and Building Materials, vol. 26, no. 1, pp. 65-73, 2012.

[6] A. Domingo-Cabo, C. Lázaro, F. López-Gayarre, M. A. Serrano-López, P. Serna, and J. O. Castaño-Tabares, 
"Creep and shrinkage of recycled aggregate concrete," Construction and Building Materials, vol. 23, pp. 2545-2553, 2009.

[7] G. Fathifazl, A. Ghani Razaqpur, O. B. Isgor, A. Abbas, B. Fournier, and S. Foo, "Creep and drying shrinkage characteristics of concrete produced with coarse recycled concrete aggregate," Cement and Concrete Composites, vol. 33, pp. 1026-1037, 2011.

[8] L. Butler, J. S. West, and S. L. Tighe, "The effect of recycled concrete aggregate properties on the bond strength between RCA concrete and steel reinforcement," Cement and Concrete Research, vol. 41, pp. 1037-1049, 2011.

[9] Y. Xu, W. Chen, R. Jin et al., "Experimental investigation of photocatalytic effects of concrete in air purification adopting entire concrete waste reuse model," Journal of Hazardous Materials, vol. 353, pp. 421-430, 2018.

[10] R. Jin, B. Li, S. Wang, O. Tsioulou, D. Wanatowski, and A. Elamin, "Experimental investigation of properties of concrete containing recycled construction wastes," International Journal of Civil Engineering, vol. 16, no. 11, pp. 1621-1633, 2018.

[11] F. T. Olorunsogoa and N. Padayacheeb, "Performance of recycled aggregate concrete monitored by durability indexes," Cement and Concrete Research, vol. 32, no. 2, pp. 179-185, 2002.

[12] G. Dimitriou, P. Savva, and M. F. Petrou, "Enhancing mechanical and durability properties of recycled aggregate concrete," Construction and Building Materials, vol. 158, pp. 228-235, 2018.

[13] D. Xuan, B. Zhan, and C. S. Poon, "Durability of recycled aggregate concrete prepared with carbonated recycled concrete aggregates," Cement and Concrete Composites, vol. 84, pp. 214-221, 2017.

[14] ASTM, Standard Specification for Materials for Soil-Aggregate Subbase, Base, and Surface Courses, ASTM D1241, West Conshohocken, PA, USA, 2007.

[15] Ispatguru.com, "Steelmaking by induction furnace, ispatguru. com," 2018, http://ispatguru.com/steelmaking-by-inductionfurnace.

[16] M. A. Qurishee, I. T. Iqbal, M. S. Islam, and M. M. Islam, "Use of slag as coarse aggregate and its effect on mechanical properties of concrete," in Proceedings of 3rd International Conference on Advances in Civil Engineering, CUET, Chittagong, Bangladesh, 2016.

[17] A. John and E. John, "Study on the partial replacement of fine aggregate using induction furnace slag," American Journal of Engineering Research, vol. 4, pp. 1-5, 2013, e-ISSN: 2320-0847 p-ISSN : 2320-0936.

[18] A. Andrews, E. Gikunoo, L. Ofosu-Mensah, H. Tofah, and S. Bansah, "Chemical and mineralogical characterization of Ghanaian foundry slag," Journal of Minerals and Materials Characterization and Engineering, vol. 11, no. 2, pp. 183-192, 2012.

[19] T. U. Mohammed, M. N. Rahman, A. H. Mahmood, T. Hasan, and S. M. Apurbo, "Utilization of steel slag in concrete as coarse aggregate," in Proceedings of International Conference on Sustainable Construction Materials and Technologies, Las Vegas, NV, USA, August 2016.

[20] ASTM, Specification for Portland Cement, ASTM C 150, West Conshohocken, PA, USA, 2007.

[21] ASTM, Standard Test Method for Sieve Analysis of Fine Aggregate, ASTM C 136, West Conshohocken, PA, USA, 2014.

[22] ASTM, Standard Specification for Concrete Aggregates, ASTM C 33, West Conshohocken, PA, USA, 2011.

[23] ASTM, Standard Test Method for Bulk Density ("Unit Weight") and Voids in Aggregate, ASTM C29, West Conshohocken, PA, USA, 2009.
[24] ASTM, Standard Test Method for Density, Relative Density (Specific Gravity), and Absorption of Fine Aggregate, ASTM C 128, West Conshohocken, PA, USA, 2015.

[25] ASTM, Standard Test Method for Density, Relative Density (Specific Gravity), and Absorption of Coarse Aggregate, ASTM C 127, West Conshohocken, PA, USA, 2015.

[26] ASTM, Standard Test Method for Total Evaporable Moisture Content of Aggregate by Drying, ASTM C 566, West Conshohocken, PA, USA, 2013.

[27] American Concrete Institute (ACI), Standard Practice for Selecting Proportions for Normal, Heavyweight and Mass Concrete, ACI 211.1-91, Famington Hills, MI, USA, 2002.

[28] ASTM, Standard Practice for Making and Curing Concrete Test Specimen in the Laboratory, ASTM C 192/C192M, West Conshohocken, PA, USA, 2007.

[29] ASTM, Standard Test Method for Slump of Hydraulic-Cement Concrete, ASTM C 143, West Conshohocken, PA, USA, 2015.

[30] ASTM, Standard Test Method for Compressive Strength of Cylindrical Concrete Specimens, ASTM C 39, West Conshohocken, PA, USA, 2015.

[31] ASTM, Standard Test Method for Splitting Tensile Strength of Cylindrical Concrete Specimens, ASTM C 496, West Conshohocken, PA, USA, 2017.

[32] ASTM, Standard Test Method for Static Modulus of Elasticity and Poisson's Ratio of Concrete in Compression, ASTM C 469, West Conshohocken, PA, USA, 2014.

[33] ASTM, Standard Test Method for Density, Absorption and Voids in Hardened Concrete, ASTM C 642, West Conshohocken, PA, USA, 2013.

[34] ASTM, Standard Test Method for Electrical Indication of Concrete's Ability to Resist Chloride Ion Penetration, ASTM C 1202, West Conshohocken, PA, USA, 2017.

[35] O. Valenta, "The permeability of concrete in aggressive condition," in Proceedings of the 10th International Congress on Large Dams, pp. 103-117, Montreal, Canada, June 1970.

[36] S. I. Ahmad and M. A. Hossain, "Water permeability characteristics of normal strength concrete made from crushed clay bricks as coarse aggregate," Advances in Materials Science and Engineering, vol. 2017, Article ID 7279138, 9 pages, 2017.

[37] J. Xiao, J. Li, and C. Zhang, "Mechanical properties of recycled aggregate concrete under uniaxial loading," Cement and Concrete Research, vol. 35, pp. 1187-1189, 2005.

[38] J. Xiao, W. Li, Y. Fan, and X. Huang, "An overview of study on recycled aggregate concrete in China (1996-2011)," Construction and Building Materials, vol. 31, pp. 364-383, 2012.

[39] V. Corinaldesi and G. Moriconi, "Influence of mineral additions on the performance of $100 \%$ recycled aggregate concrete," Construction and Building Materials, vol. 23, pp. 2869-2876, 2009.

[40] C. Lian, Y. Zhuge, and S. Beecham, "The relationship between porosity and strength for porous concrete," Construction and Building Materials, vol. 25, pp. 4294-4298, 2011.

[41] P. K. Mehta, Concrete: Structure, Properties, and Materials, Prentice-Hall, Inc., Englewood Cliffs, NJ, USA, 1986.

[42] H. Beshr, A. A. Almusallam, and M. Maslehuddin, "Effect of coarse aggregate quality on the mechanical properties of high strength concrete," Construction and Building Materials, vol. 17, pp. 97-103, 2003.

[43] R. V. Silva, J. Brito, and R. K. Dhir, "Establishing a relationship between modulus of elasticity and compressive strength of recycled aggregate concrete," Journal of Cleaner Production, vol. 112, pp. 2171-2186, 2016. 


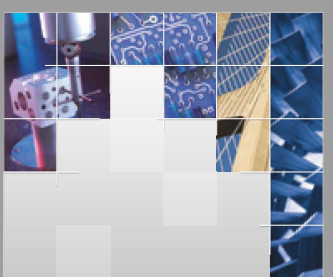

\section{Enfincering}
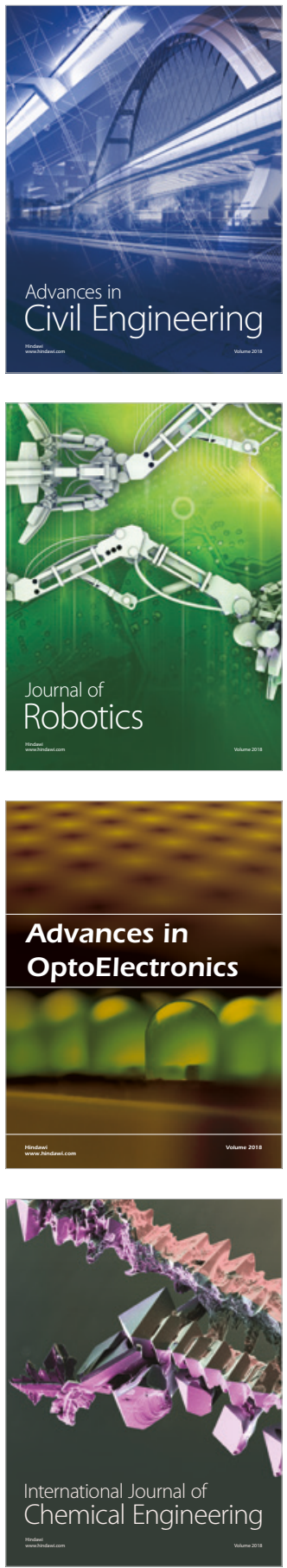

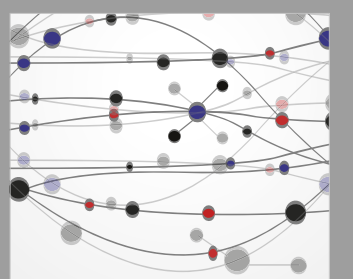

\section{Rotating \\ Machinery}

The Scientific World Journal

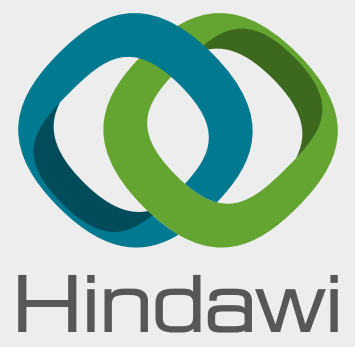

Submit your manuscripts at

www.hindawi.com
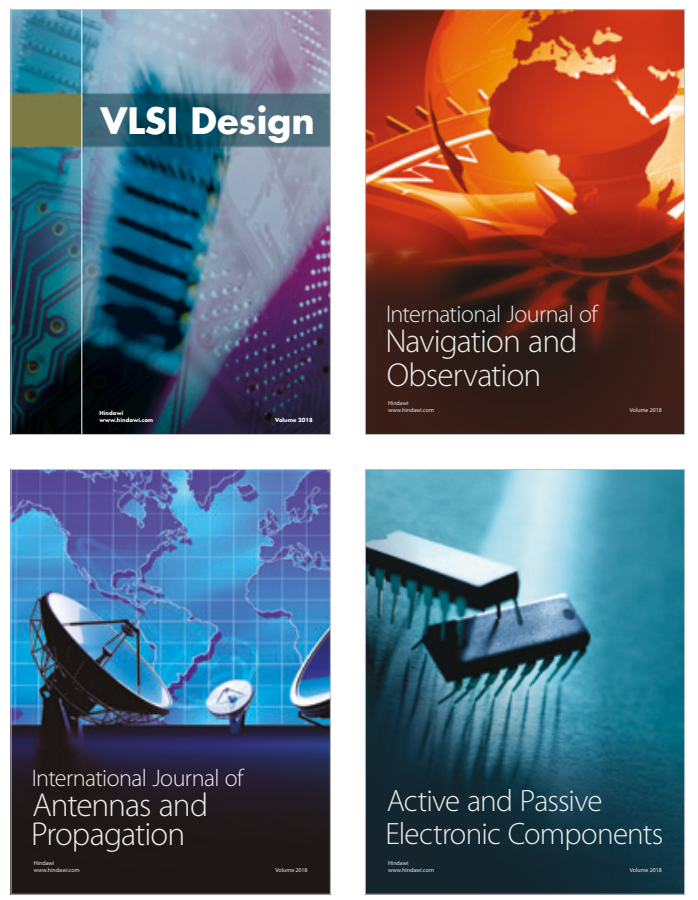
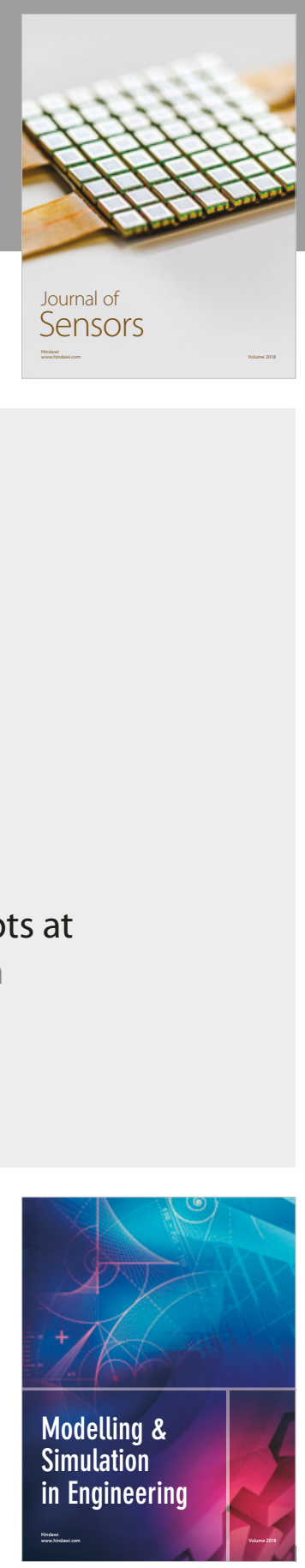

\section{Advances \\ Multimedia}
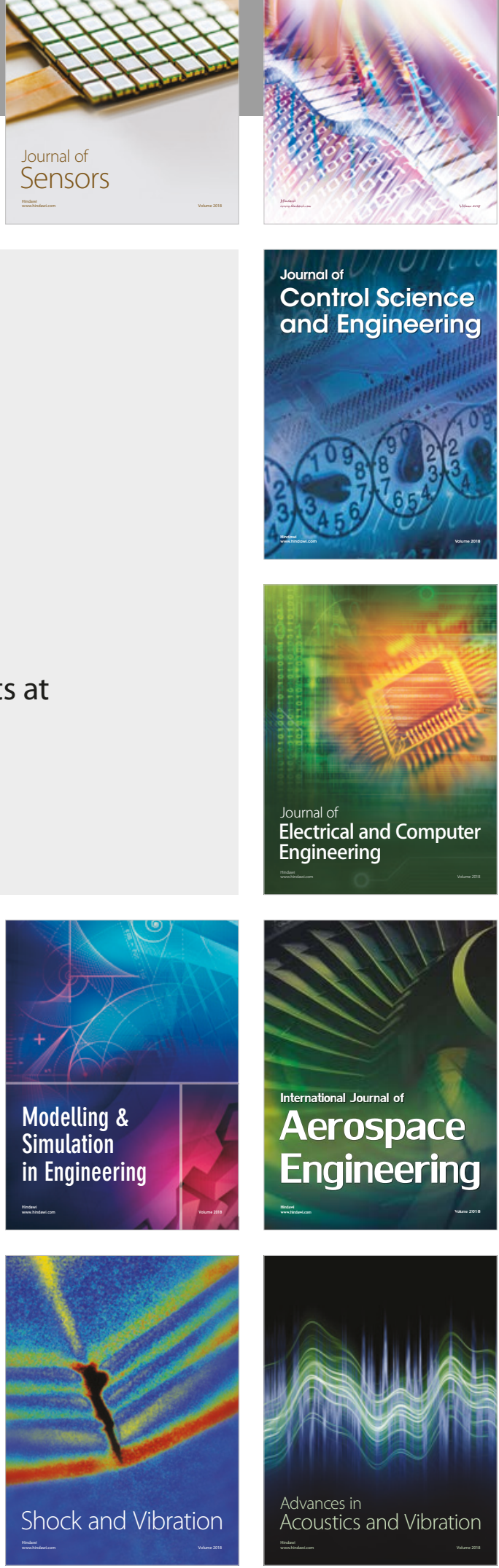